\title{
Péntek János
}

\section{Koreszmék és rögeszmék}

1. A háború utolsó telén, amikor Kolozsváron már átvonult a front, 1944. december 21-én az Erdélyi Múzeum-Egyesület szakosztályi ülésén György Lajos' emlékező előadást tartott Bálint Gáborról, születésének centenáriumán ${ }^{2}$. A mai nyugtalan békeidőket is megszégyenítő kegyeleti gesztus volt ez az emlékezés az önmaga helyzetét nem ismerö,jövőjét még kevésbé sejtő Tudományegyetem és EME részéről. Mint minden hasonló sorsforduló idején, a tẻl, a háború és a nyilvánvaló újabb uralomváltás ellenére, az előadás hangneme bizakodó volt, szinte rögeszmésen bizakodó, hiszen a keletkutatás újbóli megindításának gondolatával zárult és azzal az egyetemet érintő javaslattal, hogy „....Körösi Csoma Sándor és gr. Kuun Géza hazájában, a kolozsvári tudományegyetemen, Bálint Gábor tanszékének hagyományát újból életre kell kelteni" ${ }^{3}$.

Már a kortársak közül is többeknek lelkiismeret-furdalása volt (és lehetett!) Bálint Gábor miatt, és ez mintha az utókorra is áthagyományozódott volna. György Lajos szerint is $\mathbf{O}_{\text {a }}$ kortársaktól meg nem értett és kellőképpen nem értékelt tudós, akit az utókor méltánytalanul és hamar elfeledett. Nem ismeretlen képlet ez erdélyi tájainkon. Mert ki örizhette volna a tudós emlékét és örökségét, ki méltányolhatta volna szakmai eredményeit? Elsősorban az egyetem, amelynek 37 szemeszteren át volt professzora, és Felső-Háromszék, a szükebb szülöföld. De hát az egyetem, amely 1893-ban katedrára hivta önként vállalt számüzetéséböl, maga alig hat esztendővel élte túl Bálint Gábort, a szülőföld pedig szintén másféle gondok és félelmek nyomása alatt él több mint hetven esztendeje, elfeledve fiát, akinek sírja itt van a kézdivásárhelyi temetőben. A kolozsvári egyetem ebben az évben, 1994-ben a román egyetem 75. évfordulóját ünnepelte. A korábbi időszakról, 1872-ig visszamenőleg, nemigen akar tudni, azt a régi egyetemet, a Ferenc József Tudományegyetemet nem tekinti elődjének, és láthatólag azt sem, amely 1940-1945 között, majd 1946 után Bolyai Tudományegyetem néven mủködött 1959-ig. Már a város miatt is az ember szeretné mindezeket az egyetemeket a tanítási nyelvtől és az államhatalomtól függetlenül ugyanazon intézménynek tekinteni, Erdély egyetlen egyetemének, ám ez illuzórikusnak tünik. Mert az egyes szakterületek müvelői pontosan ismerik ugyan a száz évvel korábbi és a század eleji professzorok nagyságát: a Szinnyei Józsefét, a Brassai Sámuelét, a Meltzl Hugóét, a Halász Ignácét, a Bálint Gáborét vagy a Gombocz Zoltánét, de a mai egyetem mint intézmény mit sem tud róluk. Az ural-altaji tanszék pedig, amelyet Bálint Gábornak alapitottak 1893-ban, 1918-ban végleg megszűnt. Tekintve, hogy a szegedi egyetem a kolozsváriból jött létre, az ottani altajişztikai tanszéket lehetne a jogos utódnak tekinteni, és ez szakmai színvonalával mindenképpen méltó örököse a hajdani kolozsvárinak. D¿ hogy Bálint Gábor örökségéböl mit vállal ez a tatnszék, és hogyan értékeli az O mủködését, arról szegedi kollégáink maguk szólhatnának a leghitelesebben.

2. Bálint Gábornak életében sem volt szerencséje az intézményekkel (kivéve a kolozsvári egyetemet és az Erdélyi Múzeum-Egyesületet). Legendásan konok, kényelmetlen, nehéz ember volt már fiatal korától. És noha a szellemi függetlenség a legfőbb feltétele a tudományos munkának, az intézményeken kívül rekedő tudós csak akkor tud a pályán maradni, maradandót alkotni, ha maga biztosíthatja anyagi függetlenségét. Egyébkẻnt ki van szolgáltatva az intézményeknek és a pártfogóknak, amelyek és akik soha nem teljesen önzetlenek.

Ezt kellett tapasztalnia Bálint Gábornak Budapesten, ahol fiatalon valószínủleg nem tudott kellőképpen tájékozódni, ahogy ma mondanánk: helyezkedni. Más erdélyi tehetségekkel is

\footnotetext{
${ }^{1}$ György Lajos személyére és munkásságára nézve 1. Antal Árpád: György Lajos ẻletmüve. Erdẻlyi Tudomảnyos Füzetek 210. Kolozsvír 1992.

- Gyärgy Lajos: Bálint Gábor emlekezete. Egy kolozsvári egyetemi tanár oroszországi és belsáázsiai nyelvtanulmányai. Erdélyi Tudományos Intézet. Kolozsvár 1945.

${ }^{3}$ I.m. 31 .
} 
megtörtént, hogy azt hitték, tudásukkal és akaratukkal megváltják a világot, de a „világ”, amelybe kerültek, bonyolultabbnak bizonyult, mint ahogy ők elképzelték. Bálint Gábor is, miután Erdély minden számottevő iskoláját végigjárta, újabb és újabb nyelvtanulási lehetőségeket keresve, a váradi premontreiek érettségijével és tiz nyelv ismeretével próbálkozott előbb Bécsben, a császári Keleti Akadémián, majd az egyetem jogi fakultásán, hogy - bizonyára csalódva és józanodva - végül a pesti egyetemen kössön ki joghallgatóként és a keleti nyelvek szenvedélyes búváraként.

Végzetszerủen került Vámbéry Ármin hatása alá, és az ỏ ajánlására kapta és fogadta el azt a Fogarasi Jánostól eredő és az A kadémiától is támogatott megbizatást, hogy a magyar nyelv ázsiai (mongol, tatár, kínai) rokonságának kiderítésére végezzen helyszíni tanulmányokat. Erre 1871 és 1874 között a kazáni, majd a szentpétervári egyetemen, később 1877 végén gr. Széchenyi Béla kelet-ázsiai expedíciójának tagjaként került sor. ${ }^{4} \mathrm{De}$ ez a rövid idő is elég volt a dravida (tamil) „fertőzéshez”.

Az ugor-török háborúban élesen és durván szemben álló nyelvhasonlító és -rokonító frontokon mindkét tábor szemében rövid időn belül Bálint Gábor lett az áruló. És éppen az Ő életének a további alakulása mutatja, hogy ebben a nem ok nélkül háborúnak nevezett szakmai vitában nem csupán a tudományos érvelés pengéjét forgatták. 1877-es Párhuzamával ${ }^{5}$, amelyben a magyart az egyik legősibb és legönállóbb altaji nyelvnek állítja, a finnugor nyelvrokonság híveit, Hunfalvyt és Budenzet haragítja magára tiszteletlen hangjával és ellentmondást nem türő kijelentéseivel. Ezzel és még inkább 1879-es Pesti Napló-beli nyílt levelével ${ }^{6}$ országos botrányt kelt, helyzete lehetetlenné válik. Önkéntes számüzetéséből csak Hunfalvy halála után térhet vissza, de ekkor sem Pestre, hanem Szentkatolnára, majd a kolozsvári egyetemre.

1887-ben Bejrútból küldi el az Erdélyi Mủzeumnak A tamul nyelv a turáni nyelvek sanskritja vagy van-e a magyarnak testvére? címú tanulmányát, amely a folyóirat 1888 -as évfolyamában meg is jelent. ${ }^{\dagger}$ Ebben már a török, illetőleg ural-altaji nyelvrokonságnak is hátat fordít. Pontosabban: a turáni nyelvek körében keresi a magyar nyelv helyét és őseit. Ennek ellenére lett éppen az ural-altaji tanszék professzora Kolozsváron, és ezen a tanszéken a turánizmus eszméjének hirdetỏje a finnugorsággal és a szükebb altaji rokonsággal szemben.

3. Honnan erednek Bálint Gábor különc vagy különcködő elméletei, az akadémiai és egyetemi köröket megbotránkoztató rögeszméi? Ezek semmiképpen nem teljesen önálló hipotézisei, hanem mélyen a korban gyökereznek, és amennyiben téveszméknek bizonyulnak, elsősorban a kor téveszméi. Azt mindenképpen el kell ismerni, hogy az európai tudományosságban szokatlan módon, Bálintnak a nyelvtudása és a nyelvekre vonatkozó ismeretei nem „a szakirodalomból” erednek, hanem az élő nyelvek helyszíni tanulmányozásából. Ezek az élő ismeretek teljesen egyedülállóvá teszik az $O$ müködését, hiszen ebben az esetben a mintegy (vagy közel) 30 ázsiai nyelv ismerete nem szellemi luxus, nem önmāgában a teljesítményért van, hanem tanulmányozható nyelvì anyagként. Az európaì tudomảnyossảgban az volt a megszokottabb és a hitelt érdemlöbb, ha a nyelvész a könyvtảrban dolgozott, a könyvek anyagát hasznosította és értékelte s mintegy bizonyságkẻnt arra hivatkozott. Ahogy Verne a könyvtárban ülve kalandozta be regényeiben a föld ismert és egzotikus tájait, a nyelvészetben is Humboldtíg vagy nálunk Körösi Csomáig ritka, hogy valakinek helyszíni ismeretei legyenek távoli kultúrákról és nyelvekről. Bálint Gảbor ezt joggal érezte fölénynek elődeivel és kortársaival szemben. Bámulatos szellemi képessége és nyelvi tudása alapján azonban túlsá-

\footnotetext{
${ }^{4}$ E tanulmányút font osabb eredményeiböl l. Az éjszaki burját-mongol nyelvjárás rövial ismertetése. Nyelvtudomảnyi Közlemények (XIII) 1877. 169-248; Kazáni tatár nyelvtanulmányok. I. Kazáni-tatár szävez̧ek. Budapest 1875; II. Kazáni-tatár szótár. Budapest 1876; III. Kazáni-tatár nyelvtan. Hang-. alak-ès morulattan. Budapest $1 \delta 77$.

${ }^{5}$ Párhuzam a magyar és mongol nyelv rerén. Madsar Monghol khojor kliele aclalitklakho bicsik (Magyar mongol kẻt nyelvet egyenlitô int). Budapest 1877.

ó Egy távozó számadása (Levél a szerkesztỏhöz). Pesti Napló 1879. 107. sz.

${ }^{7}$ Erdélyi Múzeum (V) 1888, 33-55, 215-236.
} 
gosan hamar és fölényesen itélkezett, és gyakran úgy, mintha ezzel maga a megbotránkoztatás lett volna a célja.

A XVIII. század végén és a XIX. század elején kialakult a nyelvek eredetének és rokonságának a vizsgálati módszere: az összehasonlító-történeti nyelvészet. A magyar úttörök: Sajnovics János a maga Demonstratiójával ${ }^{8}$, majd az erdélyi Gyarmathi Sámuel 1799-ben Göttingában publikált Affinitasával ${ }^{9}$ módszeresen igazolták a magyar és az egyéb fïnnségi és ugor nyelvek rokoni összetartozását. Módszeresen, de nem meggyőzően azok számára, akik előkelőbb rokonságra vágytak. És a szakmában sem végérvényesen, mert a történeti kapcsolatok és a tipológiai azonosság miatt tovább is kisértett a török eredet, ami némelyek számára bizonyosság volt, az altaji nyelvekkel való távolabbi rokonság eszméje és az ural-altaji nyelvi kapcsolatok hipotézise, amelyet az időbeli távolság miatt sem körültekintően igazolni, sem meggyőzően cáfolni nem tudott azóta sem a nyelvtudomány.

Az új módszer a maga látványos bizonyitásaival, a Gyarmathitól eredő rekonstrukciós eljárás néha büvészkedő túlzásaival a nyelvészeket is megszéditette. Azt hitték, hogy a távoli múltra vonatkozó hipotézisek valóságosaknak tekinthetők, továbbá, hogy az egyes nyelvek eredetének megfejtése egyúttal a nyelvet beszélő nép eredetét, az etnogenezis helyét és idejét is egyböl megoldja, s hogy ez lehet a kulcsa az egyes kultúrák eredetének is. Ez mindenképpen túlzás volt, olyan túlzás, amelyre néhány kortárs is figyelmeztetett, hogy aztán a XX. század tegye föl az indokolt kérdőjeleket és figyelmeztető táblákat. Hogy ti. egyáltalán nem sziikségszerüen azonos és egygyökerü a nyelv, a nép és a kultúra eredete, és hogy minden, a múltra vonatkozó kikövetkeztetés módszertani hipotézis csupán, amelyet nem lehet valóságosként, bizonyosságként kezelni.

4. Volt ennek a kornak, a XIX. század első felének egy másik fontos felfedezése is. Az a felismerés, hogy morfológiai (tisztán nyelvi) hasonlóságok és különbözőségek alapján a nyelvek tipizálhatók. Ez a módszer tiszta formájában mellözi az előbbi szemlélet genetikus és történeti spekulációit és buktatóit, azokat az elhárithatatlan érzelmeket, szenvedélyeket és indulatokat, amelyekkel egy nép saját bölcsőjét, számba jöhető rokonságát, helyét keresi. Csupán egy valamit föltételez: az egyes nyelvek pontos ismeretét, hiteles leirását. A.W. Schlegel, majd az indogermanisztika más kiválóságai a mā már klasszikusnak és kissé elavultnak tekinthető három típust különitették el: az izolálót, az agglutinálót és a flektálót. A kor szelleme nem kedvezett ennek a tisztán nyelvészeti megközelítésnek, hiszen maguk a morfológiai osztályozás klasszikus szerzői is az ún. természettudományos és evolucionista szemlélet bủvkörében éltek. Ez volt tudvalevőleg a XIX. század alapvető mitosza, amely minduntalan befolyásolta, megzavarta a másféle megközelitést. Mindenféle társadalmi jelenség, intézmény - és így a nyelv - vizsgálatát behatárolta a születés - kifejlödés - leépülés - elmúlás feltételezett modellje.

Darwin fö mủve, $A$ fajok eredete 1859-ben jelent meg. Ebben a fajok fejlödésének és osztályozásának megvilágítására maga a szerzỏ hivatkozik a nyelvek analógiảjára. Arra, hogy a fajokéhoz hasonlóan, a nyelvek genetikai kapcsolatai is megállapithatók, az ember családfája - mondja - „a legjobb osztályozást szolgáltatná az egész világon ma használatban levő különbözö nyelvekre nézve ${ }^{10}$. August Schleicher volt aztán az a nyelvész, aki a darwinizmust, a természettudomány evolucionista szemléletét bevitte a nyelvtudomány elméletébe." Ennek lényege, hogy ő már nem csupán analógiát lát a fajok és a nyelvek fejlöłlése, az éló szervezetek és a nyelv között, hanem szerinte a nyelv maga élö szervezet, természeti organizmus, úgy él, keletkezik, fejlödik és hal el, mint a fajok.

A nyelvtipusokra vonatkozó elmélet és az egyes nyelvek tipológiai megitélése kezdetben

${ }_{9}^{8}$ Demonstratio. Llioma Ungarorum et Lapponum idem esse. Koppenhiga 1770.

9 Affinitas linguae Hungaricae cum linguis fennicae originis grammatica demonstrata. Güttinga 1799.

10 A fajok eredere. Budapest 1873. II. 246.

11 L. töle: Die danvinische Theorie und die Sprachwissenschaft. 1863. Magyarul: Danvin és a nyelvtuclomány. 1878. 
mentes volt a korszellem előitéleteitől. Ez azt.jelentette, hogy magukat a típusokat változatlanoknak tekintették, és hogy az egyes nyelvek tipológiai jellegét is többé-kevésbé állandónak vélték. Bár érvényesült az az inkább a középkori szellemet és a korabeli romantikát tükröző felfogás, hogy a tiszta típusok ősiek, és hogy minél ősibb egy nyelv, tipológiailag annál tisztább. Azt nyilván nem volt nehéz észrevenni, hogy tipológiailag egészen tiszta, steril nyelvek nincsenek.

W. von Humboldtnál már az újkori szemléletnek megfelelően a fejlödés a tökéletesség felé halad. Úgy véli, hogy az egységes emberi szellemi erő valósul meg különböző módon és mértékben az eltérő típusú nyelvekben, és hogy ez a megvalósulás egyre tökéletesebb. Az egyes nyelvek eltérő igerendszerére hivatkozik, ezeket tekinti osztályozása alapjának. ${ }^{12}$

5. Ez volt a kor szelleme a nyelvészetben, és ezt csak a század második felében zavarta meg a újgrammatikus irányzat, amely a nyelvi változások szabályosságára, törvényszerüségére esküdött, és e célból az élő nyelvek, nyelvjárások vizsgálatát is szorgalmazta, majd a század végén a Wund-féle pszichologizmus.

Bálint Gábort az elméletek kevésbé érdekelték. Némi bántó éllel róla is, akárcsak mesteréröl, Vámbéry Árminról, ellenfelei azt mondták, hogy nyelvészetileg képzetlen s abból eredne az önfejüségük és a különcködésük, hogy csak a saját elméleteiket ismerik, és azokhoz ragaszkodtak rögeszmésen. Vámbéry tudvalévően a magyar nyelv török eredetét vallotta és védelmezte, azt, hogy a magyar az altaji nyelvek családjába tartozik. Ezt próbálta nagy hévvel bizonyitani az emlitett ugor-török háborúban finnugrista ellenfeleivel, Hunfalvy Pállal és Budenz Józseffel szemben. És ebben lett volna szövetségese fiatal barátja és tanitványa, Bálint Gábor, aki végül bizonyos értelemben áldozata volt ennek a tudományos háborúskodásnak, majd mesterét is megtagadva a turáni elmélet hive lett.

Fogarasi János, Bálint mecénása az első ázsiai tanulmányúton, a Czuczor-Fogarasiként

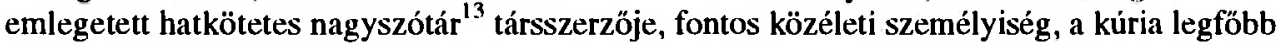
itélőszéki bírája volt. Foglalkozására nézve jogász tehát és nyelvész. Nyelvészként - akárcsak Bálint Gábort - sem a saját kora, sem az utókor nem vette komolyan. Dilettánsnak tartották vagy mükedvelőnek, szemléletét elavultnak. 1834-ben kiadott első fontosabb munkájának cime: A magyar nyelv metaphysikája v. a betüknek erederi jelentése a magyar nyelvre alkalmaztatva. A magyar nyelv szelleme címü tanulmányában, amely 1843-ban jelent meg és 1858-ban nyerte el az Akadémia Marczibányi-jutalmát, a kor élvonalbeli nyelvfilozófiai eszméi visszhangoznak.

Az ún. gyökelṃélet híve 'volt, és mint az emlitett szótár is tükrözi, a nyelvek és a szavak eredetében à nyelvmètafizikának és a hangmetafizikának tulajdonitott nagy szerepet. A szak- . tudomány ezzel akkor sem tudott és azóta sem tud igazán mit kezdeni. Ami persze önmagában még nem indokolja a "tudománytalan" vagy a „dilettáns” minősítést. Hiszen aligha lehet azt állitani, hogy a nyelvek létrejöttében és életében nem lehetett és nem lehet szerepük metafizikus, irracionális tényezőknek. Talán éppen az a fajta kognitỉv nyelvészet és szemantika, amely most kezd kìalakulni és teret hódítani, ez lesz kẻpes behatolni a nyelv irracionális, kaotikus világába, hang, érzés, sejtelem és jelentés kusza rejtelmeibe, kapcsolataiba.

A magyar nyelvtudomány története bizonyára át fogja értékelni azt a közkeletủ véleményt, hogy Fogarasi nyelvészeti müködésének egyetlen maradandó eredménye a szórend és a hangsúly viszonyának beható elemzése ${ }^{14}$, amelyet aztán Brassai Sámuel folytatott. ${ }^{15}$ Ettől függet-

\footnotetext{
12 Wilhelm von Humboldt: Uber die Kawi-Sprache auf der Insel Java, nebst einer Einleitung über die Versclue. denheit des menschlichen Sprachbaues und ihren Einfluss auf die geistige Ennvicklung des Menschengeschlechrs. I. Berlin 1836.

A magyar ryelv szótára. Budapest 1862-1874.

14 Hangsialy a magyar nyelvben. Akadémiai Értesitö 1860-1861.

15 Egy egészen friss tanulmínyból kiderül, hogy máris lényegesen módosult, kedvezôbbé vált a Czuczor-Fogarasi szótár szớfejtéseinek megitélése. L. Szilágyi Ferenc: $A$ hangutánzás és $a_{n}$ hangfestés " a magyar szófejtésben. - Tanulmámyok a magyar myelvtudomány tōrténéének témakörébôl. Szerk. Kiss Jenô és Szüts László. Budapest 1991. 658-64.
} 
lenül nem árt felidézni: Bálint Gábor elsö ázsiai útjára úgy került sor, hogy Fogarasi, aki Mongol nyelvtanulmányok címmel 1868. dec. 21-én az A kadémián értekezést olvasott fel, javasolta egy fiatal nyelvtudós kiküldetését, és erre a célra évi száz aranyat ajánlott föl. Ez is jelzi müködésének széles körét és áldozatkészségét.

6. Van ennek a kornak egy nagy hatású egyénisége, akit ma inkább téveszméi miatt szoktak ugyan idézni, ám a múlt század második felében mégis ỏ volt a nyelvtudomány prédikátora, legnagyobb hatású elöadója és legolvasottabb szerzöje. A nagyközönség körében mindenképpen. (Ez is elég gyakran elöfordul az egyes tudományok történetében, hogy a kortársak körében nem a legmélyebb, mondjuk humboldti méretủ gondolkodónak van hatása, hanem a merész, gyakran felületes általánosítóknak, akik a kötelező elővigyázatosság és kétely mellőzésével nagy dolgokat vélnek fölfedezni.) Maximilian Müllerröl van szó, Müller Miksáról, ahogyan a kor divatja szerint magyaritották a nevét. Német származású tudós volt, de Oxfordban müködött, ott tartotta „fölolvasásait”, elöadás-sorozatait a nyelvészet alapvető kẻrdéseiröl. 1861-töl ezek az előadások sok kiadásban megjelentek, és szinte azon nyomban más nyelvekre is leforditották öket: 1874-ben Simonyi (Steiner) Zsigmond forditásában magyarul is. ${ }^{16}$

Tőle való mindenekelött a turáni elnevezés, amely nála a ragozó, agglutináló nyelvek összefoglaló neve. A flektáló nyelvek indoeurópai csoportját szintén ő nevezte el árjảnak, a tởbeli flektálást mutatókat pedig séminek. Ezen a ponton, a történetiség és a nyelvi jelleg összekapcsolása révén, ki lehetett terjeszteni e terminusokat a „népfajok"-ra is, a faji és kulturális jellegzetességekre. Ezt persze már nem lehet mind a Müller számlájára írni. De azzal, hogy az egyes nyelvtipusokat kiválasztott nyelvekkel és nyelvcsaládokkal reprezentálta, és azokat a kultúra tipusaival, illetöleg fejlettségi szintjeivel is kapcsolatba hozta, ötletet és ösztönzést adott azoknak a XX. századi eszméknek is, amelyek a fajiságot és a nyelviséget meghatározónak tekintették a kulturális és szellemi teljesitmények szempontjából. $O$ ugyanis azt mondta, hogy az árja és a sémi nyelvek a fejlett földmüvelő kultúrák megteremtői és képvise$18 ̋ i$, a turániak az ázsiai nomád állattartók, az izoláló nyelvủ népek pedig a fejlettség legalacsonyabb, mintegy természeti szintjén állnak. Mindennek az alapja az a téves elmélet, amely a nyelvek és a kultúrák változását is egyirányú, lineáris (vagy akár spirális) fejlődésként feltételezi, a kettő egyes szakaszai között közvetlen párhuzamot lát, a fejlödés csúcsát pedig az árja népek nyelvében és kultúrájában véli fölfedezni.

Századunk tudományos kritikája (de már a múlt században is ható demitizáló Vico-féle filozófia is) alaptalannak tekinti mindezeket a feltételezéseket. A nyelvtipusokat nem tekinti ugyan változatlanoknak, ám a változás irányát ciklikusként föltételezi és függetlenként természetesen a kultúra változásától, amely maga sem egyirảnyú, egy szálon futó.

Megitélésem szerint Bálint Gábor, több kortársához hasonlóan, Müller csapdájába esett, a kor csapdájába voltaképpen. Meg volt ugyanis gyözödve arról, hogy az azonos jelleg közös ösiséget, közös gyökereket föltételez, és hogy azok a nyelvek, amelyek tipológiailag „tisztábbak", ösibbek is a többinél. Mindez persze lehetséges, de semmi bizonyitéka nincs, söt különösebb valószinüsége sincs annak, hogy az összes agglutináló nyelvek, azaz az ázsiai és nem ázsiai „turáni” nyelvek mind rokonai volnának egymásnak, hogy mindezek a tamil, vagy a magyar, vagy a sumér mintájára volnának visszavezethetök. (Mert természetesen a sumér is agglutináló, azaz ilyen értelemben „turáni” nyelv.)

Egyébként Bálint Gábor 1888-ban az Erdélyi Múzeumban megjelent tanulmányában, amelynek már idézett, sokat mondó címe: $A$ tamul nyelv a turáni nyelvek sanskritja vagy van-e a magyarnak testvére?, a turáni nyelvekröl mint azonos típusú nyelvekröl ír, a magyar pedig - ekkori véleménye szerint - testvér nélküli, mint a japán vagy a dravida (tamil) nyelvek. Ime néhány jellemzö részlet:

${ }^{10}$ Müller Miksa Fólolvasásai a nyelvructonányból. Az MTA kiadása. 1874. 
„....azok a nyelvek, a melyek a magyar nyelvvel megegyező sajátságúak, azok a turáni nyelvek és a tamul nyelv ezen nyelvek egyike. És megforditva, ha valaki a tamul nyelv sajátságait ismeri, tudja a turáni nyelvek mivoltát."17

„Addig, a mig a magyar nyelvészek két nagy tábora, egyaránt dicsőítve mindkettő a kürtszájú, de kutatni nem akaró tollhősöktől, azon fog vitatkozni, ha a magyar finn-ugor-e, vagy török-tatár, azt hiszem, alig fognak más eredményre jutni, mint az indiai mese szerint elefántot látott négy világtalan koldus. ${ }^{18}$

„Sc nem fïnn a magyar, se nem török-tatár, hanem a nagy turánság családjában testvér nélkül van a magyar törzs. Ama nagy család a mandsuk, a mongolok, a török-tatárok, a fïnnugorok, a tamulok vagy dravidák és a Himalája törzsök mindnyájan külön-külön testvéres csoportok...."

Semmi kivetnivalót nem lehetne ma sem találni ebben a szövegben, ha nem a turánság családjáról beszélne a szerző, hanem a turáni, azaz agglutináló nyelvek családjáról, és ha nem a magyar nyelv rokontalan voltát állitaná a családon belül. Nem a mentségére, csupán magyarázatként mondom: úgy kell Ôt látnunk, mint a nyelvek között hajózó Kolumbuszt. Rendkivüli nyelvtudásával azonnal érzékelte bármely újonnan megismert nyelv jellegét, típusát, a magyarral való jellegbeli egyezését, ám ezt mindjárt a történetiség, a rokonság nyelvére fordította le. Hogy a rokonság bizonyításának más, külön módszertana van, arról egyszerúen nem akart tudomást venni.

Jellemző erre a Zichy Jenő gr. 1895-ös, alig három hónapos kaukázusi expedíciójának tanulsága. Bálint Gábort már kolozsvári egyetemi tanárként hívták meg nyelvész szakértőnek. Ekkor a cserkeszek ejtették fabul, $s$ ami fontosabb: a cserkeszek kabard nevú törzse, nyelvjárása. Szintén turáni nyelvükben vélte felfedezni Bálint a kulcsot a hun-székely-magyar kérdés megfejtésére, amely persze szükségessé tette a honfoglalás revizióját. Az egész fejtegetésnek nem lényegtelen eleme, hogy ezzel a maga számára igazoltnak látta a hun-székely rokonság mitikus hagyományát. Már korábban is azt vallotta a székelyekröl, hogy az ázsiai őshazában az elökelők rendjét alkották, amelybe „a felvétel vitézi érdemek alapjản történt."

7. A szavaknak is megvan a maguk sorsa. A tudományos szakszavaknak is. Ahogy az embert, a szā vakát sem védi semmi a rágalmakkal, gyanúsítgatásokkal szemben. Kompromittálni lehet őket anélkül, hogy tehetnének róla vagy ellene. Jellegzetesen ez történt a turáni elnevezéssel, amely a XX. század második felében a faji vagy a fajelméletet hirdető szinonimájává vált sokak tudatában, emiatt olyan tabuszóvá, amelyet kiejteni sem volt szabad, nemhogy leírni. Bizonyára ez is lényeges oka (volt) a Bálint Gábor körüli hallgatásnak, az amnéziának. Holott egyrészt semmi nyoma nincs annak, hogy az élete utolsó éveiben indult Turáni Társasághoz bármilyen köze lett volna, másrészt a társaság és a folyóirat indulásakor és első időszakában mindenképpen szakmai jellegü volt és magas tudományos színvonalú.

Maga a Turán név egy nagy történeti régió ősidők óta használt neve. Ez a terület az Irántól északra fekvő steppe és sivatag, a Kaszpi-tenger környéke. A kultúra bölcsője bizonyos ẻrtelemben, hiszen ezen a tájon van az óvilági növénytermesztẻs kiindulópontja, centruma. (Igy talán mégsem véletlen, hogy a történelmi turáni népekhez olyanok tartoznak, mint a sumérok, etruszkok, szkíták, hunok, avarok, besenyők, kunok stb.) Már Müller részérỏl sem volt szerencsés, hogy e vidék nevét, illetőleg népeit a kevésbẻ fejlett nomád pásztorkodással kapcsolta össze (az is kérdés, hogy az kevésbé fejlett-e), és hogy az agglutináló nyelveket így nevezte meg. Az ő tipológiájában így akaratlanul pejoratívvá vált a szó. Bálintnál pedig, más magyar szerzőknél, altajistáknál, orientalistáknál, akiknek ,turáni” anyanyelvük volt, a turánsághoz egyfajta büszkeség kapcsolódott, a nagy nyelvi „család" tudata.

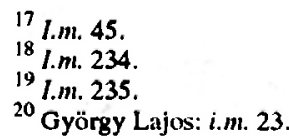


A Turáni Társaság mint akadémiai szintú tudományos egyesület 1910-ben alakult meg (nincs tudomásunk róla, hogy Bálint Gábor tagja lett volna), első elnöke az a gr. Széchenyi Béla, akinek korábbi ázsiai expedíciójában Bálint is részt vett. Az 1913-ban indult Turán címú folyóiratnak szerkesztője volt többek között a Kalevala-forditó Vikár Béla és gr. Teleki Pál is. 1920-ban alakult meg a Magyarországi Turán Szövetség, és valószínúleg ettől kezdve ment végbe a mozgalomnak az a politikai ideologizálása, ami időben visszafele és magáig a szóig elmenöen mindent és mindenkit kompromittált. Közvetve az ebben az ügyben teljesen ártatlan Bálint Gábort is. Lehet persze, hogy mindez csak feltételezés, mégis intő jel arra, hogy elő kell vennünk megrágalmazott, gyanúba kevert szavainkat is, mert gyakran ez a feltétele annak, hogy fontos eszméket, intézményeket és személyiségeket méltóképpen értékelhessünk.

8. Külön, az illető szakterületek mai kutatóira vár annak megítélése, milyen értéket képviselnek Bálint Gábor konkrét nyelvleírásai, az a nyelvi anyag, amelyet három ázsiai útja alkalmával gyüjtött, majd publikált. Vagy még azt megelözően: van-e valamilyen értéke fiatalon irt Török nyelvtanának ${ }^{21}$ Aztán az első, hosszabb útján gyűjtött tatár népköltészeti anyaga, hiedelemgyüjtése, szótára, nyelvtana, amelyet Kazáni tatár nyelvtanulmányok címmel adott ki 1877-ben, megőrizte-e forrásértékẻt? Gyaníthatólag ezek Bálint Gábor munkásságának legértékesebb és legmaradandóbb értékei. És ide sorolható Tamul (dravida) ranulmányok ${ }^{22}$ cimü munkája és nyelvi anyaga révén Kabard nyelvtana (Kolozsvár 1900) és szótára is (Lexicon cabardico-hungarico-latinum. Kolozsvár 1904).

Ha csupán e munkákat nézzük vagy ezek bármelyikét, akkor is el kell ismernünk Bálint Gábor kivételes tudományos teljesítményét. Az elméletekben rendszerint kevés az időtálló, de a pozitiv tudás, a pozitiv ismeret, a tényanyag megmarad. Az elméletekkel az a baj, hogy ami a legfontosabb volna bennük és velük kapcsolatban, a kétely, a kritikai reflexió, az tünik el leghamarabb, és a legtetszetősebb hipotézis is viszonylag gyorsan rögeszmévé merevül. A tudomány nagy és szent dolog, de a tudósok távolról sem szentek, hanem emberek. Gyarló emberek, tele göggel, hiúsággal, önzéssel, elfogultsággal. És konoksággal.

9. Talán ezért is van, hogy akiket mitikusan nagy tudósoknak tekintenek, csak ritkán érzékeny nevelök is egyben. Bálintnak is bizonyára nagy hallgatósága lehetett, lehettek hivei harcaiban, vitáiban, akiket magával ragadott szenvedélyes megszállottsága, ragyogó tudása, ellenzékisége. Nyitott és fogékony volt olyan új dolgok iránt, amelyek rögeszméit nem érintették Magyar egyetemen $\varnothing$ volt az első, aki már 1897-ben, tíz évvel e nyelv megszületése után, eszperantó tanfolyamot tartott, és „kőnyomatos” ivekben kiadta az eszperantó nyelv szabályait. Amikor pedig Barabás Ábel kolozsvári unitárius kollégiumi tanár ennek alapján megírta az Esperanto világnyelv címü könyvét (1898), elöszavảban Bálint Gábor védelmébe vette ennek „a logikán alapuló nyelvnek ésszerüségét és észben tartható könnyủségét”23. Éppen O̊ pártfogolta az eszperantót, aki a legkevésbé szorult rá, hiszen tanította a törököt, a tatárt, a japánt, a kabardot, a mandzsut, a tamilt, a finnt.

Hívei voltak tehát, de igazi értelemben vett tanítványai nem.

10. Talán akad majd egyszer vállalkozó, aki alaposan elemezze: kiket és mi okból emelt mitoszi magaslatra az utókor emlékezete? Kivánatos volna többet elmélkednünk a mitizálódás transzilván mechanizmusáról, modelljéről is, amely nẻha érthetetlen, bántó amnéziával párosul. Miért van az, hogy némelyeket teljesen elfeled az utókor, míg másokat az egekig magasztal? A tudósokat tekintve és éppen Bálint Gábor példảját, semmiképpen nem lehet azt állitani, hogy önmagában a tudományos teljesitmény volna a leglényegesebb az így vagy ủgy ítélkező utókor szemében. Már nyelvtudása miatt is bárhol a világon legendás alakként tisztelnék. Nálunk nem. Még az egyetem hajdani évkönyveiben is csak két címe szerepel: „az

${ }^{21}$ Török nyelvtan. Alak-. mondattan, olvasókönyv és szótár. Budapest 1875.

:- Tamul (dravida) tanulmányok: Gróf Széchenyi Béla keletásiai átjanak tudományos eredménye. Budapest 1897. İ. I-34l.

${ }^{23}$ György Lajos: i.m. 22. 
irak-arabi török tartomány pénzügyi ellenöre és a kolozsvári egyetem tiszteletbeli doktora”. Az sem mindennapi, hogy tudományos viták áldozataként lett önkéntes számüzött. Hogy három ázsiai tanulmányutat tett említett száınüzetésén kívül, és minden útjának gazdag volt a tudományos termése.

Igaz viszont, hogy zárkózott volt és különc. Különc volt a tudományban, de ez a különcködés jórészt (vélt) nemzeti érdekü, nemzeti indíttatású volt, és külön szerepet játszott benne, mint jeleztük, székely volta, a székely eredetmítosz tudományos igazolásának szándéka.

Különc volt emberként is: öltözködésében, magatartásában, ellenzékiségében. Don Quijote-i figura volt. ${ }^{24} \mathrm{Nem}$ igazodott, nem törleszkedett sem intézményekhez, sem hatalmasságokhoz. Nemłkereste senki kegyeit. Az utókor kegyeit sem.

Az utókor aztán gyorsan el is feledkezett róla. Némi cinizmussal és iróniával azt is mondhatnánk: ha Bangalorban halt volna meg, ott volna eltemetve, Hozzá is zarándokként járnánk, mint Körösi Csomához. De mivel itt nyugszik a kézdivásárhelyi temetöben, senki nem törödik vele. Pedig megérdemelné. Ha nem is az indokolatlan mitizálást (annak ủgyis bővében vagyunk), az emlékezést és a megbecsülést mindenképpen.

11. Ha pedig Körösi Csomát említettük, ejtsünk néhány szót a hely szelleméröl is. Annak a helynek a szelleméról, ahonnan Bálint Gábor elindult, és ahová pihenni is visszatért.

Ebben a régi szentkatolnai kastélyban, amelynek szép termében az emlékülést tartjuk, egy másik neves orientalista is megfordult. Osdolai gr. Kuun Gézáról van szó. Az O̊ neve is összekapcsolódik e tájjal, hiszen Ozsdola itt van Szentkatolna és Csomakőrös tőszomszédságában, bár a családnak ez az ága már rég Hunyad megyében élt, Kuun Gézának a marosnémeti kastély volt az otthona: 1847 nyarán még mint gyermek járt Szentkatolnán, mint visszaemlékezéseiben írja: „...nagybátyám gr. Kuun József meghivására Háromszékbe utaztunk, a ki ezen nyárra átadta nekünk szentkatolnai kastélyát... E kastélyt Háromszék egykori fötisztje, ősöm, zabolai Basa Tamás épittette a XVII. évszáz elsỏ felében; egyik leánya Kún Istvảnhoz ment férjhez, a másik Mikeshez Zabolán. Két kastélyt épittetett Basa Tamás, az egyiket Szent-Katolnán Kún Istvánnénak, a másikat Zabolán Mikesnénak. Kún István leánya Bethlen Miklóshoz ment férjhez, Erdélyország korlátnokához s híres államférfihoz, ki utóbb grófi méltóságra emeltetett. Kún Ilona fiatalon halt meg. Kủn Istvánék többnyire az osdolai kastélyban laktak s Kún IIlona fényes esküvője is ott volt. A szentkatolnai kastély nagy csínnal és kényelemmel volt berendezve." 25

Szádeczky Lajos mondta róla temetésén: „Utolsó képviselöje volt köztünk egy — sajnos - letünni látszó szép világnak, mellyel Erdély századokon át tündökölt: a fớri tudósoknak."26

Nem volna illő Bálint Gábort ünnepelve a Kuun Géza tudományos érdemeit ecsetelni az orientalisztika területén. A hely szelleme miatt mégis szóba kellett hoznom, és azért is, mert róla sem emlékezett meg senki az elmúlt negyven esztendőben.

Csomakőrös - Zabola - Szentkatolna - Ozsdola: itt van egymás tőszomszédságában. Hảrom híres orientalistánk neve kapcsolódik ezekhez a szẻkely falvakhoz, amelyeknek határa ezer éven át az ország határa is volt a keleti végeken. Talán nem teljesen véletlen, hogy éppen e keleti végekröl indultak a távoli Keletre saját törzsük gyökereit keresve. Volt ebben a hỏsi, néha romantikus nekibuzdulásban megszállottság és rögeszme, az eredetmitoszokban való konok hit. De az eredmény: kinek-kinek az életmüve, a Bálint Gáboré különösen, az egyetemes és a magyar tudományt gazdagította. A székely eredetkérdés tudományos megoldása pedig valószínủleg éppen azért nem juthat nyugvópontra, mert a XX. századi tudomány is csak egymást és a korábbi véleményeket kizáró újabb rögeszméket tud felmutatni.

\footnotetext{
-4 Az én megitélésem szerint korintsem véletlen, hogy éppen Vetró András mintảzta meg Bảlint Gảbor Szentkatolnán felavatou mellképét, hiszen az Ō müvészi pályájảt végigkiséri Don Quijote jelképes alakja.

${ }_{25}^{25}$ Gyermekéveim. Erdélyi Múzeum (XXI) 1904. 549-51.

${ }^{20}$ Erdélyi Múzeum (XXII) 1905. 228.
} 